\title{
SHARIA, TWO SIDES OF THE SAME COIN: THE CONTRADICTIONS BETWEEN SHARIA AND ADAT (Case Studies of Minangkabau's Matrilineal and Land Tenure System)
}

\author{
ADRI WANTO ${ }^{1}$ \\ S. Rajaratnam School of International Studies, \\ Nanyang Technological University, Singapore
}

\section{Abstract}

Since the implementation of regional autonomy laws in Indonesia, large numbers of sharia-inspired laws have been implemented in the West Sumatera Province. Furthermore, some Minangkabau people, the ethnic group indigenous to the province, have insisted in the abolishment of the matrilineal and land tenure system, which they believe is not in accordance with sharia. For hundreds of years, the Minangkabau ethnic have been famous for being one of the world's largest matrilineal societies, and the inheritance of land and property ownership is handed down according to the matrilineal principle over generations. As a result, conflicts arise within indigenous communities (internal conflict-horizontal) since its proponents and opponents are equally strong in the society. The most interesting aspect to be analyzed is the fact that the disputing groups use sharia to legitimise their points of view. Some argue that the matrilineal and land tenure system is in accordance with sharia while the others argue otherwise. This study will focus on the discourse beyond the epistemic claim made by the disputing groups. This paper argues that the mix of ideological, political and economic interests play a significant role behind the struggle

\footnotetext{
${ }^{1}$ Ph.D. student of Austronesian Studies, Asia-Africa-Institute (AAI), University of Hamburg, Germany. Corresponding author; email: isadriwanto@ntu.edu.sg
} 
for control of the religious discourse, particularly related to the matrilineal and the land tenure system in the Minangkabau post reformasi era.

Sejak pelaksanaan undang-undang otonomi daerah di Indonesia, banyak terbentuk undang-undang yang terinspirasi dari bukum syariah dan telah diterapkan di wilayah Provinsi Sumatera Barat. Terlebih, beberapa kelompok masyarakat Minangkabau sebagai etnis asli provinsi tersebut, bersikeras dalam hal penghapusan budaya matrilineal dan sistem kepemilikan tanah, yang mereka percaya tidak sesuai dengan syariah. Selama ratusan tahun, etnis Minangkabau terkenal sebagai salah satu masyarakat matrilineal terbesar di dunia, demikian pula pemberian warisan tanah dan kepemilikan lahan atau bangunan diturunkan sesuai dengan prinsip matrilineal tersebut. Sebagai akibatnya timbul konflik dua kubu dalam masyarakat adat yang sama kuat. Aspek yang paling menarik untuk dianalisis adalah kenyataan bahwa kelompok yang bersengketa itu menggunakan syariah untuk melegitimasi pandang mereka masing-masing. Sebagian kelompok berpendapat bahwa sistem kepemilikan matrilineal dan tanah adalah sesuai dengan syariah sementara yang lain berpendapat sebaliknya. Studi ini akan fokus pada wacana klaim epistemologis yang dibuat oleh kelompok-kelompok yang bersengketa. Tulisan ini berpendapat bahwa campuran kepentingan ideologi politik dan ekonomi memiliiki peran penting di balik perjuangan untuk mengendalikan wacana keagamaan, terutama berkaitan dengan matrilineal dan sistem kepemilikan tanah di Minangkabau pada era pasca reformasi.

Keywords: matrilineal; land tenure; Islamic movement; adat; sharia.

\section{Introduction}

Since the fall of the Soeharto regime in 1998, Indonesia has been considered to be one of the world largest and most decentralized democratic countries. As a home to numerous different ethnic groups, democratic consolidation for some groups 
was viewed as an opportunity to renegotiate their local cultural position in Indonesia's political domain. Since the laws No. 22 \& 25/1999 on Regional Autonomy were implemented, ${ }^{2}$ some ethnics in Indonesia asked for replacement of the Desa $a^{3}$ system with a governmental structure based on their own a traditional customary rule (adat), such as Gampong in Aceh, Pekon in Lampung, and Kampong in Papua and East Kalimantan. Similarly, in the West Sumatera province, the Minangkabau ${ }^{4}$ people asked for replacement of the Desa with the Nagari ${ }^{5}$ in the entire Minangkabau area (Asnan 2003, 529; Fanany 2003, 180-83). The idea of "babaliak ka nagari" or returning to nagari was one of the most crucial political issues of the democratic consolidation in West Sumatera. Ultimately, based on West Sumatera provincial regulation (Perda) No. 2, 2007, the Desa was replaced with the Nagari system.

Returning to Nagari, for Minangkabau people, simply means returning to their adat and Islamic teaching (Franz and Keebet von 2006, 239-42; Fanany 2003, 180-83). They believe that Minangkabau culture and Islam are two inseparable identities.

${ }^{2}$ The regional autonomy laws no. 22 \& 25/1999 has been undergone two revisions: regional autonomy laws No. 32 in 2004 and No. 23 in 2014.

${ }^{3}$ Desa is a top-down centralized political system adopted from Javanese political system. Based on law No. 5/1979, the Desa system is the lowest administrative level all over Indonesia which is recognized by the Indonesia government.

${ }^{4}$ The term 'Minangkabau' also known as 'Minang' refers to the ethnic group indigenous to the West Sumatera province, Indonesia. In Minangkabau language, the term can also refer to their land as well as their culture and tradition. Therefore, the word 'Minangkabau' is often used interchangeably.

${ }^{5}$ Nagari is the lowest administrative level in Minangkabau and has sovereign status, was autonomous, and had governed its people in a democratic manner. It is made up of a territory, a political structure and its own legal system. To become a nagari, the community had to fulfil certain requirements: minimum of four tribes already settled in the area; a meeting point where people can gather (balai adat); a mosque (masjid), arable areas; roads and an access to water (tapian tampaik mandi). See Kato (2005, 2-3). 
In their social system, adat should be based on Islamic teaching (Abdullah 1966, 1; Navis 1991, 1-8; Hamka 1984, 3-15; Abunain 1991, 1-14). The collaboration between adat and Islamic teaching in establishing the Minangkabau religious community is reflected in a famous Minangkabau adat aphorism, well-known as a Marapalam ${ }^{6}$ Charter: " "Adaik basandi syarak, syarak basandi Kitabullah, syarak mangato, adaik mamakai" (Minangkabau customary rules are founded upon sharia and sharia is founded upon the Holy Book, whatever the sharia says, Minangkabau customary rules will follow) (Simarmata 2006, 160).

Ultimately, following the implementation of regional autonomy laws, large numbers of sharia-inspired laws have been implemented in Minangkabau. As part of their demand to implement sharia, some Islamist ${ }^{8}$ groups also began to reject the

${ }^{6}$ Marapalam is the hill at the bottom of Mount Sago in Lintau, Tanah Datar Region West Sumatra.

${ }^{7}$ There is no certainty as to when the charter was declared at Marapalam hill. There are five versions about when the agreement was made. The first version mentioned that it was declared in 1644 . In the second version, there is no certainty about which year it was but it was not long after the Wahabi movement occurred in Mecca. The third version says it was in the early days of the Padri War from 1803 to 1819. The fourth version claims it was during the unrest after the Padri war. The fifth version states that it was before the hills of Marapalam were controlled by the Dutch in 1832. See Asoka (1991) and Abunain (1991, 1-14).

${ }^{8}$ In some cases, the use of 'Islamist' has created an epistemological problem. Fuller argued that "Islamist is one who believes that Islam as body of faith has something important to say about how politics and society should be ordered in the contemporary Muslim World and who seeks to implement this idea in some fashion"(Fuller 2003 introduction). In the context of dispute on Minangkabau Adat, fuller definition is considered inapplicable examine the fact that the proponents and opponents of Minangkabau adat use sharia to legitimise their point of view. Therefore, instead of using Fuller's definition, the term 'Islamist' here is referring to Islamic groups influenced by Salafism and Wahabism, an ultra-conservative reform movement that advocates a return to Quranic times, which are also actively propagate their 
Minangkabau's matrilineal and land tenure system as an effort to purify 'the Islamic teaching'. The Minangkabau are famous for being one of the world's largest matriarchy ${ }^{9}$ societies and the inheritance of land and property (harta pusaka) ownership is handed down according to the matrilineal principle over generations. They argued that both Minangkabau's customary systems were not in accordance with sharia, which is 'patriarchal' in nature.

The most interesting aspect to study is the fact that those who support the Minangkabau customary rules also use sharia to legitimise their point of view. On one hand, the proponents argue that Minangkabau adat is in accordance with sharia while the opponents argue otherwise. Hence, the questions to be addressed in this study are: How can we explain this puzzle and understand why such contradictions take place? Why is sharia interpreted differently by different Islamic groups in Minangkabau? Who is seen as an epistemic authority with the respect of theory of knowledge that brings Minangkabau's society partic-

interpretation of Islam in West Sumatera.

${ }^{9}$ Matriarchy is usually defined as a political system in which women are the dominant political actors, as opposed to patriarchy, in which men are the exclusive or primary heads of families, social groups, or political states. In the sense of women-domination of politics, it is repeatedly stated by scholarly authorities that there are no matriarchal societies in the world today (and many argue there never were). Perkins Gilman ([1915] 1992) called Matriarch as utopian theory; Marshall (1998) called as deluded fantasy, and Frazier (1949) and Moynihan (1965) called as dangerous degeneration or dysfunction. Heide Göttner-Abendroth (2004) defined the matriarchy as women "hav[ing] the power of disposition over the goods of the clan, especially the power to control the sources of nourishment," and distinguishes this actual distributive power from "mere" matrilineality or matrilocality. Therefore, Matriarchy here is not defined as the mirror image of patriarchy, in which women domination of politics. Rather, matriarchy is a system in which women are considered to be at the centre of the social and economic system. For further discussion on this matter, see Sanday (2003). 
ular perspective, values, assumption, and meaning? Who can be consulted and respected with the regard to knowledge production in Minangkabau society? Who is credible? Who is ignored? What is the motive behind the struggle for control of the sharia discourse in Minangkabau, related to the matrilineal system and land tenure issues? How important are the Minangkabau scholars in providing answers to the problems confronting contemporary Minangkabau society?

Drawing from the fields of anthropology, Islamic studies, and political science, this study will look closely at the discourse of Islam, adat, and democracy in the West Sumatera province since the implementation of regional autonomy law. This study will also look at the slow evolution of Minangkabau people's interpretation of Islam and adat by investigating the social identity of actors and agents that give particular religious perspectives, assumptions, values and meanings to the Minangkabau people. Using the critical discourse analysis approach, this study will focus on the discourse beyond the epistemic claims made by opponents and proponents of the matrilineal and the land tenure systems in Minangkabau.

In collecting data and resources, the author employed primary source information gathered through field research and interviews with adat and Islamic community leaders,local parliament members, social activists, government officials, and grass-root Muslims in Minangkabau. The field research was conducted in rural and urban areas of the West Sumatera province. We studied the contextual condition in the urban and rural areas of Minangkabau as comparative studies by focusing on the social, institutional and environmental conditions that may have a strong influence on Minangkabau people's points of view toward Islam and Minangkabau adat. In the rural area, the field research was conducted in Tanah Datar, well-known as lubak nan tuo, the 
center of the Minangkabau ethnic group, where adat values are still well-maintained. In the urban area, the study was conducted in the cities of Padang, Padang Panjang, Bukittinggi and Solok, where the contiguity and high interaction with other cultures, people, capitals and ideas have come about as a part of the process of globalization.

\section{Epistemological Discrepancy}

Since the fall of the Soeharto regime, like elsewhere in Indonesia, Islamist purification movements are increasing their influence in West Sumatera. Besides the local Islamic mass organisations, such as the Islamic Law Enforcement Committee (KPSI), Gerakan Muslim Minangkabau (GMM), and Islamic Defender Society Front (FMPI), the Java-based Islamic organisations such as, Hizbut Tahrir Indonesia (HTI), Majelis Mujahidin Indonesia (MMI) and the Islamic Defender Front (FPI) have established local branches in the province. These organizations have actively persuaded the Minangkabau people to join their movements in promoting the implementation of sharia. Since the implementation of regional autonomy laws No. 22 \& 25/1999, large numbers of local regulations based on the sharia have been implemented. As many as 26 sharia laws have been implemented in the province, see Table 1.

Table 1

List of Perda Syariah implemented in

West-Sumatera since reform era

\begin{tabular}{cl}
\hline Year & \multicolumn{1}{c}{ Regional Autonomy Laws } \\
\hline 2001 & - $\begin{array}{l}\text { Provincial level: Provincial regulation number 11/2001 on } \\
\text { the Control of, and Action of, Social Illnesses. } \\
\text { - Tanah Datar Regent, Mayor Instruction letter Number } \\
\text { 451.4/556/Kesra-2001 on the Imposition of the obligation to } \\
\text { wear Islamic Outfit for civil servants. }\end{array}$ \\
\hline
\end{tabular}




\begin{tabular}{|c|c|}
\hline Year & Regional Autonomy Laws \\
\hline 2001 & $\begin{array}{l}\text { - Solok Regent, Local regulation Number 10/2001 0n Quranic } \\
\text { Literacy for Pupils, Students, Brides, and Grooms-to-be. }\end{array}$ \\
\hline 2002 & $\begin{array}{l}\text { - Solok Regent, Local Regulation Number } 6 / 2002 \text { on the Is- } \\
\text { lamic outfit. }\end{array}$ \\
\hline 2003 & $\begin{array}{l}\text { - Padang Regent, Local Regulation Number } 6 / 2003 \text { on the } \\
\text { comprehensive Quran Literacy for Regular and Islamic Ele- } \\
\text { mentary School Students. } \\
\text { - Padang Regent, Local Regulation Number } 3 / 2003 \text { on the } \\
\text { - Somprehensive Quran Literacy for Muslims. } \\
\text { Malok Regent, Local Regulation Number } 13 / 2003 \text { on the } \\
\text { Contribution. } \\
\text { - Bukittinggi Regent, Local Regulation Number } 20 / 2003 \text { on } \\
\text { the amendment of the local regulation Number } 09 / 2000 \text { on } \\
\text { the Control of, and Action of, Social Illnesses. } \\
\text { - SawahLunto Regent, Local Regulation Number } 01 / 20030 \text { n } \\
\text { Quranic Literacy for Pupils, Students, Brides, and Grooms- } \\
\text { to-be. } \\
\text { - Sawah Lunto Regent, Local Regulation Number } 02 / 2003 \text { on } \\
\text { the Islamic outfit. } \\
\text { Pasaman Regent, Local Regulation Number } 22 / 2003 \text { on the } \\
\text { obligation to wear the Islamic outfit for Students and Em- } \\
\text { ployees. } \\
\text { - Pasaman Regent, Local Regulation Number } 21 / 2003 \text { on the } \\
\text { comprehensive Quranic Literacy. } \\
\text { Pesisir Selatan Regent, Local Regulation Number } 31 / 2003 \text { on } \\
\text { the Management of Profession Alms and Any Kind of Chari- } \\
\text { table Contribution. } \\
\text { Lima Puluh Kota Regent, Local Regulation Number } 6 / 2003 \\
\text { on Quranic Literacy for Pupils, Students, Brides, and Grooms- } \\
\text { to-be. }\end{array}$ \\
\hline 2004 & $\begin{array}{l}\text { - Padang Pariaman Regent, Local Regulation Number 02/2004 } \\
\text { on the Prevention and Eradication and Suppression of Social } \\
\text { Illnesses. } \\
\text { - Padang Panjang Regent, Local Regulation Number 03/2004 } \\
\text { on the Prevention and Eradication and Suppression of Social } \\
\text { Illnesses. } \\
\text { - Bukittinggi Regent, Local Regulation Number 29/2004 on } \\
\text { the Management of Profession Alms and Any Kind of Chari- } \\
\text { table Contribution. } \\
\text { - Pesisir Selatan Regent, Local Regulation Number 08/2004 on } \\
\text { Quranic Literacy for Pupils, Students, Brides, and Grooms- } \\
\text { to-be. }\end{array}$ \\
\hline
\end{tabular}


SHARIA, TWO SIDES OF THE SAME COIN

\begin{tabular}{|c|c|}
\hline Year & Regional Autonomy Laws \\
\hline 2005 & $\begin{array}{l}\text { - Provincial level: Provincial Regulation number 07/2005 com- } \\
\text { prehensive Quranic Literacy. } \\
\text { - Provincial level: Governor circulation letter number } \\
260 / 421 / X / P P r-05 \text { on the obligation to wear the Islamic out- } \\
\text { fit for civil servants. } \\
\text { - Pesisir Selatan Regent, Local Regulation Number 04/2005 on } \\
\text { Islamic outfit. } \\
\text { - Agam Regent, Local Regulation Number 06/2005 on the Is- } \\
\text { lamic outfit. } \\
\text { - Padang Regent, Mayor Instruction Number } 451.422 / \text { Bin- } \\
\text { sos-III/2005 on 07 March } 2005 \text { on the obligation to wear a } \\
\text { Headscarf and the Islamic Outfit (for Muslims) and Sugges- } \\
\text { tion (for Non-Muslims). } \\
\text { - Padang Regent, Mayor Instruction on } 7 \text { March } 2005 \text { on the } \\
\text { obligation to wear the Islamic outfit for Muslim Women. }\end{array}$ \\
\hline 2006 & $\begin{array}{l}\text { - Sawah Lunto Regent, Local Regulation Number } 192006 \text { on } \\
\text { the Prevention and Eradication and Suppression of Social Ill- } \\
\text { nesses. }\end{array}$ \\
\hline 2008 & $\begin{array}{l}\text { - Padang Panjang Regent, Local Regulation Number 07/2008 } \\
\text { on the Management of Profession Alms and Any Kind of } \\
\text { Charitable Contribution. }\end{array}$ \\
\hline
\end{tabular}

Source: Law and Human Right Bureau of West Sumatera Province, "Daftar Inventarisasi Rancangan dan Produk Hukum Daerah Kabupaten/Kota Se-Sumatera Barat”

As part of their demand to implement sharia, the Islamist groups that have been influenced by Wahabi and Salafi ideology have begun to reject the Minangkabau's matrilineal and land tenure systems as an effort to purify 'the Islamic teaching'. With their emphasis on a strict, legalistic, and exclusive understanding of sharia, they argued that the matrilineal and land tenure system is against sharia laws. They believe that Arabic Islam is the highest achievement of culture. They consider Islam and Arabic culture to be virtually synonymous. Other cultures may have positive elements, however, Arabic language and culture is the critical standard by which all other cultures may be judged because God chose to give His final revelation through the Arabic language and culture. According to this interpretation, Islam 
should rule every aspect of life and create Islamic cultures wherever there are Muslims. In an interview, Afnorizal Abukasim, a ninik mamak, a tribe leader, from Bukittinggi, stated that:

"Islam is God's teaching. Human culture must not replace Islam. Therefore, we oppose the matrilineal and inheritance land ownership in Minangkabau. God, through the Prophet Muhammad, has given the rules for human life. Muhammad's position was as a representative of God on earth and man is obliged to manage their lives in accordance with the rules that God established. Therefore, we must obey and submit to God. Sharia is the rules set by God that must be implemented in the life of society and humanity." 10

A large number of both historical and anthropological works on the Minangkabau of West Sumatera have argued that contradiction between Islamic law and adat is considered to be inconsistent in Minangkabau life (Blackwood 2001). However, this study offers a different perspective. This study argues that the unresolved puzzle concerning whether Minangkabau's matrilineal and land tenure systems are compatible or incompatible with sharia actually occurs because of the semantic differences in the use of the term sharia among Minangkabau people. Hobbes (1651, 21-22) argued that there is no essential relationship of signification between the signifier (the word or sign) and the signified (the idea). Even though the proponents and opponents of Minangkabau adat use the same word, such as; sharia, matrilineal, harta pusaka, it has different meanings to them.

Also, the proponents and opponents of Minangkabauadatare actually committed to a private language theory of meaning. Locke (1690) argued that words or signs actually refer to the ideas of the speaker. Locke defined language as made up of

${ }^{10}$ The interview was conducted on 25 November 2015. 
words or signs that must refer to ideas in the mind of the language-user. In other words, the meaning (and the verification of its truth value)is determined by what the individual/group of speakers had in their mind. Based on this premises, the words such as 'sharia, matrilineal, adat, and harta pusaka', have to be viewed as epistemologically constructed through and on language. It consequently constructs artificial meanings that are the products of human mental reasoning and judgment.

We cannot deny the fact that epistemology is a social-contracted idea that has been produced in particular context. Therefore, epistemology is political (Alcoff 2013, 817-20). The ability to have control over religious epistemology has political ramifications because it enables the establishment of hierarchical religious epistemic authorities to decree how society should act or believe. The proponents and opponents of Minangkabau adat are contesting to become the religious epistemic authority that is able to determine the fixed meaning of religious epistemology. Then, they respectively claim that their interpretations on adat and Islam are objective, universal, absolute, eternal, single truths and 'immune' to criticism. They have also tried to delegitimize each other by using religious epistemology.

There are plenty of historical instances of how political crises in Minangkabau have come about as a result of contestation over religious epistemology. For instance, the conflict between the Padri group and the Syathariah Sufi order in the $19^{\text {th }}$ century was a result of doctrinal conflict and disagreement over the meaning of the terms tawhid, kafir, and sharia. ${ }^{11}$ Likewise,

${ }^{11}$ This argument may conflict with the conclusions reached by Christine Dobbin (1977, 1-38). She argued that the rise of the Padri movement in Minangkabau was due to a rise in large scale commercial revival in the west coast of Sumatera in the $19^{\text {th }}$ century. I am aware that we cannot deny the fact that Padri group was grounded in material-economic realities; however, it is also important to note that there was significant discourse behind the rise of the Movement. 
the current dispute within Minangkabau society related to their adat system is connected to the contestation to have a control over adat and religious epistemology (Zakariya 2011, 195-203). The contestation between the proponents and opponents of $\mathrm{Mi}$ nangkabau adat to have control over religious epistemology has created polarized society as a result of the epistemological discrepancy.

By confronting emic ${ }^{12}$ (Kottak 2006, 47) and etic ${ }^{13}$ perspectives, the author finds the inconsistency in religious and adat terms among the Minangkabau people who live them and the scholars who have studied them. The failure to confront etic and emic approaches has led many people to become trapped in a misleading perception about the relationship between Islam and Minangkabau adat. Some scholars have only interpreted the Minangkabau adat partially. Based on our literature research, some scholars unintentionally failed to present the real meanings given of live events experienced by Minangkabau people by ignoring the epistemological discrepancy that occurred from within. Instead, they imposed their pre-established concepts and postulates. For example, the premise that Minangkabau people follow the matrilineal system is a false statement when we utilize Minangkabau people's own epistemology of the family system. Likewise, the premise that the inheritance of land and property ownership in Minangkabau is against sharia law because it is handed down according to the matrilineal principle over generations was also a false statement according to Minangkabau

${ }^{12}$ The emic approach is perspectives from within the social group (from the perspective of the subject) in explaining how local people think, how they perceive and categorize the world, their rules for behaviour, what has meaning for them, and how they imagine and explain things.

13 The etic approach refers to generalizations about human behaviour that are considered universally true, and commonly links cultural practices to factors of interest to the researcher (scientist-oriented) from outside (from the perspective of the observer). 
people's epistemology on the land tenure system.

Based on interviews with local ulama in Tanah Datar, they argued that the tenure system in Minangkabau is in accordance with sharia. From this point of view, sharia distinguishes between two kinds of practice; namely, 'ibādat (practices concerning the relations between God and human beings, or devotional practices) and mu'àmalat (social ethics, i.e., the part of the law that guides the relations between humans). The 'ibädat includes the shalāt (prayer), zakāt (almsgiving), fasting during the holy month of Ramadan, and the hajj. The 'iba adat are constant and do not allow for varying interpretations based on spatial and temporal circumstances. Meanwhile, the mu'ämalat is a set of rules ( $f q h)$ related to worldly matters such as business, trading, commerce transactions, lending and borrowing contracts. $M u^{\prime}$ 'amalat also involves the rules regarding the social interactions between humans such as marriage, inheritance (waqf, fara$i d h)$ and other human activities that require interpretation or ijtihād. In an interview with Afrizal Tuanku Mudo, traditional ulama from Minangkabau (who lives in Batam), stated that:

"Matrilineal and land tenure systems in Minangkabau are purely mu'ämalat related matters that require Minangkabau people to perform ijtihād that takes into account the evolving 'urf or 'a dah. Having said that, the Matrilineal and land tenure systems that we are still practicing are actually based on $i j m \bar{a}^{\prime 14}$ ulama in Minangkabau"

Mr. Afrizal was referring to an $i j m \bar{a}$ ' which was held in Bukittinggi from the 4-5 May 1952 and in Padang in 1968. The ijmā' essentially concluded that the land tenure system in Minangkabau is not contrary to sharia. Furthermore, selling inheritance

${ }^{14}$ In Islamic jurisprudence, $i j m \bar{a}$ ' is the doctrine that the consensus of those with sufficient knowledge to practice $i j t i h \bar{a} d$, or independent judicial reasoning, constitutes one of the sources of fiqh. 
in Minangkabau is considered as harām, prohibited according to the sharia. The ijmā' related to the land tenure issues were constructed due to the status of the land in Minangkabau tradition. It is divided into two different categories; firstly, harato pusako randah, low property or matrimonial property. Secondly, harato pusako tinggi, high property or property that belongs to a clan. There is no disagreement over the status of harato pusako randah that is private property. If the owner dies, the property will be distributed to his/her heirs in accordance with the rules faraid $^{15}$ and the property is able to be sold.

Contradictory to harato pusako tinggi, ulama at that time concluded that harato pusako tinggi had been separated from the matrimonial property. They concluded that the status of harato pusako tinggi was similar to waqfic and musabalah property that was practiced by Caliph Umar ibn Khatthab over a plot of his land in Khaybar. Umar Bin Khatthab gave his land in Khaybar to be used by the entire population. Due to the mandate of the first owners of the land, the descendants of Umar Ibn Khatthab have no right to own land, let alone to sell it.

Similar to harato pusako tinggi in Minangkabau, this property is not considered to be private property, but belongs to the community. According to fiqh law, the status of harato pusako tinggi is a musabalah, means that property ownership is collective. Due to the land property status, when the user died, the

${ }^{15}$ Faraidh is a division of the estate after the death of a Muslim who has been prescribed under Islamic law on the legal heirs and entitled (as daughter, wife, husband, mother, father, etc.). The property is divided into the remaining heirs property left after all the funeral rites of financing, whether debt heir of the religious (like charity, vows, etc.) or due to human and will discharge permitted by law.

${ }^{16} \mathrm{~A}$ waqf is an unconditional and permanent dedication of property with implied detention in the ownership of God in such a manner that the property of the owner may be extinguished and its profit may revert to or be applied for the benefit of mankind except for purposes prohibited by Islam. 
property is not passed on to the heir but returned to the clan. The property is devoted to a common fund for their entire clan. Each member of the clan can use but cannot own it (Syarifuddin 1984, 269-70). To be specific, this property only covers property objects; land, gardens, houses, graveyards, and pools.

Ijmā' of ulama in Minangkabau at the time decided that the inheritance in Minangkabau tradition over harato pusako tinggi did not mean to transition property from the private owner to their heir, but to transfer the rights to manage the land over to the harato pusako tinggi inheritance. Based on an interview with Yus Datuk Perpatih, a prominent Minangkabau adat expert, he stated that:

"The management of harato pusako tinggi in Minangkabau is similar to the change of management of a foundation that manages the certain property. The death of a caretaker does not bring any influence on the status of the property. The status of harato pusako tinggi is totally different from the form of inheritance that is private. According to Fiqh laws, the transition of private property from the dead to the living is handing it down according to faraidh. Meanwhile, for harato pusako tinggi means a change of care takers, not of the ownership.

In Minangkabau, the harato pusako tinggi is considered a legacy that proves the "origin" of a person is of Minang descent (Minangkabau ethnic). Someone who no longer has the harato pusako tinggi in Minangkabau is not considered to be a complete Minangkabau ethnic. The harato pusako tinggi has the role as a unifier of the community of clan members, as well as to determine the origin of indigenous descent path. As such, harato pusako tinggi property also has a role as a reserve property, if there is an urgent need for clan member accordance with the provisions of indigenous customs. Based on interviews with 
Mak Datuak:

"Can we imagine if harato pusako tinggi inheritance in Minangkabau is sellable? The Minangkabau society would experience the same fate as the other ethnics in Indonesia. They would be eliminated from their native village because their property would be taken over by the bourgeois and capitalists. The harato pusako tinggi is a mandate from the first owner, which is intended to be used but not to be owned as a private property. Therefore, we don't let the property disappear or vanish from our hands. The property is not private property, but it is for the common good. We have to keep it for the next generation. In the management of this property, there is only the right to use it; there is no right of ownership, so it is a great sin if the property is sold."

The commonly accepted concept that the inheritance of land and property ownership in Minangkabau is against sharia law because it handed down according to the matrilineal principle over generations is now being challenged by the occurrence of epistemological discrepancy among Minangkabau people. Unfortunately, there is not a single study that has been conducted concerning religious and adat epistemological discrepancy related to the Matrilineal and land tenure systems in Minangkabau. As a logical consequence, some scholars have made hasty conclusions regarding the matrilineal and land tenure systems in Minangkabau.

Some scholars specifically argue that the matrilineal and land tenure systems in Minangkabau are not in accordance with sharia (Kato 2005, 1; Jeffrey 2008; Jong 1960; Sanday 2003; Graves 1984; Kahn 2007; Drakard 1999; Blackwood 2001; Reenen 1996; Dobbin 1987). The premise was developed on the basis of an assumption that the sharia is in essence patriarchal in nature and thus Muslim women are considered inferior to men; where 
Muslim women depend on close male relatives in matters concerning maintenance, divorce, and guardianship (Esposito 1982, 48; Hjarpe 1983, 15; Schact 1964, 126; Anderson 1967, 221). Emphasising this contradiction, Tsuyoshi Kato $(2005,1-4)$ even predicted that the matrilineal system in Minangkabau would decline as the Islamisation of the Minangkabau people progresses. She argues that "How such a (matrilineal) system could work in conjunction with the patrilineal Islamic legal framework has excited a good deal of speculation" (Kato 2005, 1).

For more than two centuries, almost all the anthropologists and historians who have studied Minangkabau argue that both Minangkabau adat are not compatible with Islam. Reeves Sanday (2003) makes a compelling argument:

"Minangkabau in its gender egalitarianism is a true matriarchy. Undoubtedly, the seeming contradiction of Islam and the matrilineal system has shaped the past two hundred years of Minangkabau history. The society has struggled with conflict, namely, Islamic inheritance, child custody, and residence laws, which are patrilineal and patrilocal, while the Minangkabau affiliated with large clan houses that are passed down from one generation of women to the next, defined by a common female ancestor”.

A similar hasty conclusion was drawn by Edwin Loeb. $\mathrm{He}$ argued that Minangkabau social and political organizations are a bewildering mixture of pagan, matrilineal, Hindu and patrilineal-oriented Islam (Loeb 1934, 27). Jan Prins also argued that Islam and Minangkabau customary laws are not in agreement. Prins acknowledged that Minangkabau society is thoroughly Muslim and many prominent Muslim Indonesians are of the Minangkabau ethnic. However, he argued that Minangkabau matrilineal system seems to contradict with Islamic teaching. 
Prins emphasized that a husband has no real power over his wife and children and this contradicts with the patrilineal-oriented Islam (Prins 1951, 283-300). Prins $(1951,51)$ also quoted Snouck Hurgronje as saying that:

"This dispute would lead to a more or less rapid victory of sharia, because nowhere in the world would Islam tolerate a matrilineal system to regulate relationships and matrimony in the family, in the long run."

Franz and Keebet von Benda-Beckmann also claim that Minangkabau customary laws seem to contradict sharia laws. They argue that Minangkabau tradition is famous for its matrilineal principles structuring descent groups, property and inheritance as well as political leadership. Meanwhile, sharia laws provide a very different model of social, economic and political organization and male authority. They claim that the struggles between the two systems and their protagonists have become well-known in Minangkabau (Franz and Keebet von 2006, 239). They argue that:

"When Islam and the sharia came to West Sumatera in the 16th century, it encountered a local political and legal system that was rather different from the sharia's blueprint for social, economic and political relations." (Franz and Keebet von 2006, 239)

When studying Minangkabau history, this postulation has led some scholars to conclude that the Padri movement was a pioneer against the Minangkabau matrilineal and land tenure systems in Minangkabau. Hadler (2008, 8-9) believed that Padri movement resisted it. While evidence showing Padri's declared jihad against Minangkabau matrilineal structure was never provided. He argued that; 
"The Padri certainly could not reconcile the Minangkabau matrilineal and matrilocal longhouses with the essential teachings of Islam. However, the neo-Wahabis did not upset the matriarchal system in West Sumatera."

Similarly to Hadler, Abdul A'la describes that Tuanku Nan Renceh, one of the founders of the Padri movement, sent a powerful message to the Minangkabau by killing his own aunty. A'la wrote,

"Tuanku Nan Renceh was responsible for the suffering of the elderly woman who happened to be his own aunt. When the poor women died, he decreed the body should not be properly buried, but be thrown away in the bushes. The lady was killed by the Padris simply because she ate sirih leaves" (A'la 2008, 284-85).

If Tuanku Nan Renceh really killed his aunt simply because she ate sirib leaves, which is not even considered makrub ${ }^{17}$ in Islam, how could Hadler argue that the Padri never declared jihad against the matrilineal and heritance land ownership in Minangkabau, if it was against the essential teachings of Islam? Hadler's argument conflicts with the anecdotal evidence given by A'la.

Different historical evidence linked to the end of $19^{\text {th }}$ century, however, provides an alternative perspective on the rise of resistance against the local matrilineal structure. The idea to challenge the sharia and the matrilineal and land tenure systems in Minangkabau arose at the end of the $19^{\text {th }}$ century. The first ulama $^{18}$ who argued that the matrilineal and land tenure systems

17 The word 'makrub' literally means something 'disliked', 'not recommended' or 'undesirable'. According to sharia it is any action that one is told not to do without making it prohibited.

18 Ulama literally mean "those who have knowledge" or "those who know" (singular 'alim, plural 'ulama). The term is most widely used to refer to the scholarly class of Muslim societies, whose main occupation is the study of the texts that make up the Islamic Tradition (religious sciences such as $\mathrm{Qu}$ - 
were not in accordance with sharia law was Shaikh Ahmad Khatib Al-Minangkabawy ${ }^{19}$. Commenting on the land tenure system in Minangkabau, he wrote a book titled, "Al-Dā'il al-Masmū' fī al-Raddi 'alā Man Yūrìts al-Ikhwah wa Aulād al-Akhawāt ma'a Wujūd al-Ushl wa al-Furū'”.

Likewise, Evers (1975, 87), Moubrey (1931), and Maretin (1961, 168-95) have even insisted that the Minangkabau matrilineal system is being replaced by a more patrilineal oriented system as the Islamisation of the Minangkabau people progresses. In contrast to many predictions, the matrilineal system in $\mathrm{Mi}$ nangkabau is far from disappearing. Among many scholars who argue that Minangkabau customary laws seem to contradict with sharia laws, Taufik Abdullah has shown that sharia and Minangkabau customary laws have not necessarily led to corresponding legal and political struggles (Abdullah 1966, 1-24). In his writing, Abdullah has shown that the matrilineal and land tenure systems were justified by sharia and Minangkabau people's understanding about sharia was very dynamic. Similarly, Abdul Karim Amrullah and Hazairin, also argue that the cultural assimilation between Islamic culture and Minangkabau local culture was justified by sharia (Hazairin 1982, 62). The traditional Islamic groups and Islamist groups in Minangkabau, have different interpretations toward sharia and Minangkabau adat.

ran, Hadith, tafsir, jurisprudence, and theology, but also the applied sciences such as medicine, biology, astronomy, and mathematics).

19 Shaikh Ahmad Khatib al-Minangkabawy (1860-1916) was born in Koto Tuo, Ampek Angkek, Agam Regency, West Sumatra on 6 Dzulhijjah $1276 \mathrm{H}(1860 \mathrm{M})$ and died in Mecca on 8 Jumadil Awwal $1334 \mathrm{H}$ (1916 M). He served as the head (Imam) of the Shafi'i school of law at the Mosque of Mecca (Masjid al-Haram). Many Indonesian Islamic reformist leaders learned from him, including Ahmad Dahlan, as founder Muhammadiyah and Hasyim Asyari, as founder Nahdlatul Ulama. 


\section{Cultural Assimilation in Minangkabau}

Snouck Hurgronje, who wrote about the 'Indonesian' community in Mecca during the 1880s, pointed out that the relationship between Muslims in this region and in the Middle East was unique. On one hand, the Indonesian people sought knowledge and inspiration from the Muslims in the Middle East, but they then adapted this knowledge to their local culture which was different from the source (Hurgronje 2007, 243-52; see Azra 2003). Minangkabau society is not an exception to this phenomenon. The cultural assimilation between Islam and local culture considered as adaptable and intelligent of Muslims from this region to mix Islamic teaching and their local culture to create a very rich religious synthesis (Geertz 1968, 121-26; Woodward 1989, 83-89).

Based on the author's interviews with some local ulama, they argued that the cultural assimilation between Islamic culture and Minangkabau local culture was justified by Islamic teaching, as can be seen from the Islamic traditional text (kitab kuning), especially ushul fiqh (the reason for the principles of jurisprudence) books, that have been used for hundred years in Minangkabau. In an interview with Zakirman Tuanku Sutan, a teacher at Pesantren Nurul Yaqin, Ringan-ringan, Padang Pariaman stated:

"Ultimately, I am in agreement with the opinions that there has been a cultural assimilation between Islamic culture of the Middle East and the Minangkabau culture. Nevertheless, the argument that matrilineal and the land tenure systems in Minangkabau are not in accordance with sharia is a haphazard argument. They don't understand the nature of sharia".

Mr. Zakirman emphasized that some religious leaders especially those who had been influenced by Salafi and Wahabi 
ideology in West Sumatera could not distinguish the difference between sharia and $f i q h^{20}$. This raises its own problems because the two terms have significant differences, although they also have a close relationship. Sharia is a rule that exists in the Quran and is believed by Muslims to be a provision that aims to regulate the life of the holy Muslim community. On the other hand, when a Muslim faces an issue that is not directly addressed by the sharia, the Quran asks Muslims to use the fiqh. This is using their own mind, based on what the Quran tells them, making their own decision about what action to take (Al-Zuhaili 1986). Clearly, the sharia and fiqh are very different. The sharia covers laws and principles of Islamic teachings, while fiqh is concerned with decisions made by Muslims in daily life (Sirry 1996, 18). Although the actual meaning of sharia and fiqh are different, they are flexible and combine to create what Muslim people refer to as 'Islamic sharia law'.

There are three differences between the sharia and fiqh. Firstly, the sharia is the revealed law of God contained in the Quran, while fiqh is the conclusion that Muslim people make in decision making, drawing guidance from the sharia law. Secondly, the sharia law is definite and unchanging, written in the Quran. In contrast the fiqh changes in according to the situation and condition where it is applied, and the different interpretation of each Muslim. Thirdly, most of the sharia laws are general, basic principles. Meanwhile, fiqh law relates to specific issues showing how the basic principles of sharia could be applied according to

${ }^{20}$ Fiqh is usually understood as Islamic jurisprudence. It is the practice of discovering God's law (sharia), writing treatises about it, and relating the practice of law to revelation. Historically, fiqh arose from a systematic analysis of the Quran and Hadith combined with rigorous analogical reasoning, qiyās. In both Shi'i and Sunni' Islamic circles, this led to various "schools" madhhabs, which were based regionally or other ideas of an eponymous founder. 
different circumstances (Philips 2000, introduction). Nevertheless, the fiqh can be interpreted as Islamic sharia law. However, 'legal' here does not necessarily mean legislation (rules/law) enforced by the government and state. Instead, Islamic sharia is closer to the concept of religious ethics of Islam. The main feature of Islamic law is not only the realization of rewards and punishment on the earth but also the consequence of punishment in the afterlife for wrong doing (Azizy 2003, 14-15; 2002, 13).

Moreover, Muslims have taken into account the importance of awareness and wisdom to make the historical reflection to the early Islamic period in creating Islamic fiqh thought (Hallaq 2009, 7-13; Ash-Shiddiqy 1966, 42). In the fiqh books written by Abu al-Hasan al-Mawardi, Muhammad Ibn Idris asySyafi'i, Zakaria al-Anshari, and Yusuf al-Qardhawi shows that there were many cultures that existed in the pre-Islamic era, which were adopted and practiced by the prophet Muhammad. Prophet Muhammad created many rules of customary law that were legalized in Arab society to create the opportunity for the practice of customary law in the Islamic legal system (Khadduri 2010, 15-21). Hajj and Umrah were practiced in Arab societies, long before Islam arrived. Arab societies conducted worship, as carried out by Muslims today, including: talbiyyah, ibram and wuquf. After the arrival of Islam, the practices continued with some changes. For example, thawaf was performed naked by the Arab society (Karim 2003, x-xi). The Muslims banned this and instead carry out this worship fully dressed.

The laws established by Prophet Muhammad and his successors (Shahabat) always took into account the evolving culture of the community. Caliph Umar, for example, adopted the postal service system which is a community tradition of Sasanid and the Byzantine empires (Karim 2003, 3-13). In the establishment 
of fiqh we can see the influence of different cultures in the laws that were created. Abu Hanifa ${ }^{21}$ took advantage of customs and social habits of a diverse range of communities as a secondary source to the law as long as they did not contradict with the Quran (Lukito 2001, 11). Similarly, Imam Malik was influenced by Medina indigenous communities when developing fiqh theory (Philips 2000, 99-104; Lukito 2001, 21).

Similarly, based on fiqh books that are emerging in the traditional Islamic boarding schools (pesantren) in West Sumatera, this perspective of Islamic law teaches that the new approach must be in accordance with 'urf (local culture and traditions). For instance, in the fiqh books; such as Al-Ushul min ' $\mathrm{Ilm}$ al-Ushul (The Principle of the Knowledge Principle of Islamic Law) written by Muhammad bin Sholeh al-Utsaimin, it is stated that Islamic law is adaptable to social change. 'Urf, often translated as 'culture' in English is described as the product of human idea (Tylor 1871, 1; Koentjaraningrat 1974, 11). Qardhawi explains that ' $u r f$ is the habits and behaviour of people in everyday life which become hereditary customs, both the words and behaviours, whether general or specific (Qardhawi 1996, 30). Raymond Williams defines three categories of culture. Firstly, culture can be used to refer to a process of intellectual, spiritual and aesthetic development. Secondly, culture can mean a particular view of life from a certain society. Thirdly, culture can refer to intellectual practices, especially artistic activity (Storey 1997, 2-3). These definitions illustrate that the cultural sphere is both very broad and general. Peter L. Berger adds that culture is the totality of human products, both material and non-material

${ }^{21}$ Abu Hanifa was the founder of the Hanafi "school of Sunnı" law. Little is known about his life. He lived in Kufah as a cloth merchant and collected a great number of traditions, which he passed on to his students. He never held any official post or worked as a judge ( $q$ adli). 
(Berger 1967, 8-10). Because the 'urf is an inseparable part of a person, it is used in formulating the fiqh law (Shabana 2010, 59-60).

Evidence shows that many cultures that existed in the pre-Islamic era were adopted and practiced by the prophet Muhammad. This indicates that Islam was not born in order to eliminate the entire culture of the pre-Islamic Arab society. Prophet Muhammad created many rules of customary law that legalized Arab society and so enabled the practice of customary law in the Islamic legal system. This suggests that the Prophet Muhammad did not force Arab society to change their culture, as long as the law was not against the principles of the fundamental teachings of Islam. The significance of the role of culture in Islamic law was later practiced by Prophet Mohammad's successors. Thus, culture has an important position in the history of Islamic law. It is also proved that the cultures that develop in the Islamic community do not have to obey Islamic law following the Arab style, but rather the Islamic law should be made to adapt to each culture of each community as long as it does not contradict the fundamental teachings and spirit of Islam. Not all 'urf conflicts with Islamic teachings and therefore, they can be used as the source of Islamic law.

One important factor which explains social influence in the cultural constructs of Islamic fiqh is related to the phenomenon of Imam Syafi'i. His school of thought is followed by the traditional Muslims in Indonesia. The history of his life shows that his thinking was strongly influenced by the surrounding community. In his book Al-Umm and fiqh books written by ulama who follow the Syafi'i tradition, including Mukhtashar al-Muzannī, al-Lubāb fī al-Fiqhi al-Syāfi' $\bar{\imath}$, al-Iqnā' fì al-Fiqhi al-Syāfi' $\bar{\imath}$, it is shown that social conditions and circumstances affected most of Imam Syafi'i's thoughts of fiqh law. The clearest example of this 
is the emergence of the so-called qaul qadim (the old statement) and qaul jadid (new statement) in the spectrum of thought of Imam Syafi'i. Originally, Imam Syafi'i made a statement for fiqh. However, later this statement became qaul qadim (old statement) because he came across a new situation which led him to create a new statement or qaul jadid. This indicates the flexibility of fiqh.

Josept Schacht, who interprets the sharia as a set of religious rules the totality of God's commandments that are in place to help Muslims govern their behavior in daily life (Schact 1964,1), is completely opposite to many traditional ulama in Minangkabau. Based on the aforementioned perspective about sharia and fiqh, traditional Muslims in Minangkabau, believe that Islamic law is understood as a doctrine associated with the dimensions of the time and place. Changing the time and place must influence the interpretation or $i j t i h \bar{a} d^{22}$ in Islamic law. The ability to adapt Islamic law is flexible and can be applied to every time and place ( $f \bar{i}$ kulli zamānin wa fī kulli makānin). Syatibi (1302 H.) in his book, al-Muwafaqāt fi Ushül al-Sharīah (The Reconciliation of the Fundamental of Islamic Law) wrote that "The rules of sharia have been designed to produce benefits (mashalih) and remove evils (mafāsid) and these are certainly their ends and objectives." The mashälih are those which promote the preservation and fulfillment of human life, and the realization of all that human nature and rationale demands, until one is happy in every respect.

The late Abdurrahman Wahid, a former Indonesian President, conceptualized the localized Islamic teaching. Localised Islamic teaching is interpreted as an attempt to hold onto the

${ }^{22}$ A word derived from the same root as jihad, 'to strive or make an effort, to exert oneself, in jurisprudence it means the exercise of independent judgment by one who has sufficient knowledge'. 
cultural roots of Indonesia, while still trying to create a religious community (Wahid 1989, 96). Wahid tried to position Islam and other cultures in a dialogic position. From this basis, he refused the movements of "Islamisation", "Arabisation" or "the formalization of Islamic teachings in the cultural sphere". Secondly, he argued for the respect of local traditions. In this case, Islamic law should be considered as a local tradition, not as an object that must be defeated, but as the positioning of Islamic law in the dialogic dimension.

\section{Salafi-Wahabi Influence in West Sumatera}

There is a trend among some Minangkabau people to embrace the Salafi-Wahabi ideology to understand the interpretation of sharia. This religious point of view has acquired great support from a majority of Muslims in the urban areas of Minangkabau, such as Padang, Padang Panjang and Bukittinggi. Based on an interview with Irfianda Abidin Datuk Penghulu, the Chairman of the Islamic Law Enforcement Committee (KPSI) of West Sumatera, he stated:

"Although sharia regulations have not been implemented thoroughly in West Sumatera, we can see an increasing growing consciousness to enforce Islamic laws and practices at the society level. Therefore, besides struggling for the implementation of sharia regulations, we have to focus on the society as a focal point". ${ }^{23}$

Salafi-Wahabi groups always attempt to control the fixed meaning of Islamic vocabulary such as sharia, kafir, syirk among others. The ability to have control over Islamic discourse is an important 'symbolic' resource that defines the power base of Minangkabau Muslim communities and a first major form of controlling Minangkabau peoples' thoughts and behaviors. By

${ }^{23}$ The interview was conducted in November 2015. 
controlling Islamic discourse, they are able to simply tell society what to believe or what to do. They actively propagate their religious interpretation through social media such as Facebook and Twitter. ${ }^{24}$ Beside quotes and posts of some verses from the Quran and Hadith to show the contradiction between sharia and Minangkabau Adat culture to the members of the groups, the supporters of Salafi- Wahabi groups also quotes some western prominent anthropological scholars, such as Peter L Berger, Christine Dobbin, Jane Drakard, J.L. Esposito, Elizabeth E. Graves, Jeffrey Hadler, Tsuyosh Kato, who have argued that the matrilineal and land tenure systems contradict with $\mathrm{x}$. They frequently upload the scholars' papers to the Facebook groups.

Social media is a crucial tool for Islamic purification groups to disseminate their religious interpretations and is an easy way to connect with Minangkabau people on a personal level. Grassroots Minangkabau people are their passive target. In the a fore mentioned Facebook groups, the supporters of the Islamic purification groups consistently and frequently post their arguments attacking Minangkabau matrilineal and land tenure systems. Currently, their interpretation of sharia has begun to be integrated into laws, rules, norms, and habits among Minangkabau Muslim society and thus takes a form of "cultural hegemony" among the society of Minangkabau.

With their emphasis on a strict, legalistic, and exclusive un-

${ }^{24}$ There are planty of facebook groups created by the supporters of Islamic purification ideas aiming to eliminate the matrilineal and the land tenure system in Minangkabau, among other: Perjalanan Islam Dalam Menyempurnakan Adat Minangkabau, (https:/www.facebook.com/groups/islam.minangkabau/?ref=ts\&fref=ts); Tinjauan Kritis: Doktrin Adat Minangkabau, (https://www.facebook.com/groups/583868944982653/?ref=ts\&fref=ts); Gerakan Penegakan Syariat Islam Dalam Budaya Adat Minangkabau, (https://www.facebook.com/groups/144908092370479/?ref=ts\&fref=ts),Komoditas Peduli Adat Syarak Minangkabau, (https://www.facebook.com/ groups/kpa.minangkabau/_ 
derstanding of sharia, the Islamic purification groups have pursued to divide society into "the house of Islam" (dār al-Islām) and "the house of the enemy" (dār al-harb), resulting in a perception that non-Muslims and "the West", are permanent "enemies of Islam.” They always emphasize their religious identity by following the doctrine al-Wala' Wa al-Bara' (defining people in two extreme views, Muslims, and non-believers). For instance, in 2013, Lippo Group had to revoke their Rp. 2 trillion investment project to build a hospital (Siloam) and school in Padang city because of the Islamist groups' protest against what they call the 'Christianisation' of the province. For many Islamist leaders, James Riady, the owner of Lippo Group uses his project to spread Christianity in Padang. The Indonesian Ulama Council (Majelis Ulama Indonesia) in Padang rejected all forms of investment by Riady's groups. ${ }^{25}$ The supporters of the Islamist movement created a Facebook group to disseminate their concern, namely, Umat Islam Sumatera Barat Menolak Investasi Bermuatan Misi Pemurtadan, with 73,089 members in the group. ${ }^{26}$

In the political context, the Salafi-Wahabi groups believe that Islam not only lays the fundamentals of worship but also of politics and the state (din wa daulah) (Tahrir 2005, 14-89). They believe that the country's political legitimacy should be based on sharia. Therefore, they are always fighting to establish sharia as the basis of the laws in Indonesia, including in the West Sumatera province. In an interview with Mahyeldi Ansharullah, Mayor of Padang city, from Prosperous and Justice Party (PKS), he stated that:

25 Interview with Buya Gusrizal, Head of Majelis Ulama Indonesia (MUI), conducted in November 2015.

26 https://www.facebook.com/groups/ranahminang.tolak.pemurtadan/; accessed 31 August 2016. 
"The application of sharia laws in Padang is an obligation, as Minangkabau society upholds religious and $\mathrm{Mi}$ nangkabau traditional values. The commitment to religion and tradition is clearly stated in the guiding philosophy of life of Minangkabau people, adaik basandi sarak, sarak basandi Kitabullah. West Sumatera province is left behind compared to Aceh and South Sulawesi, in implementing sharia. Therefore, we have to work extra hard to implement the sharia laws." 27

At the national level, a survey conducted by the Research Centre for the Study of Islam and Society (Pusat Kajian Islam dan Masyarakat, PPIM) of Syarif Hidayatullah Islamic State University showed a trend of Indonesia's Muslims becoming more religious, pious, and growing more conservative. Conducted in 2001, the survey showed that religious identity is important to Indonesians when they assess the prospective quality of their government and leaders. The survey showed that 57,8 percent (in 2001) and 67 percent (in 2002) of Indonesians supported the idea that the Indonesia political system should be based on Islamic teaching. The West Sumatera province is not an exception to this trend. As well as the establishment of sharia laws at the provincial and regional levels, the religious discourse in West Sumatera, especially in the urban areas, is controlled by Islamists. They actively propagate their religious interpretation through social media. By doing so, they are confident that their religious worldview will become the worldview that is imposed and accepted as the cultural norm and as the universally valid dominant religious interpretation that justifies their political actions in Minangkabau. Currently, most urban Minangkabau people tend to voice their support for the implementation of sharia laws.

${ }^{27}$ The Interview was conducted in November 2015. 
According to a report by the Setara Institute, in the West Sumatera province, the rate of politicisation of religion is particularly high. This province recorded the second highest number of incidents of violations to freedom of religion in Indonesia (Hasani 2009). For instance, at the beginning of 2012, a civil servant, Alexander Aan, posted a message on the Facebook page 'Atheist Minang', which he created. The post so enraged residents in Aan's hometown of Pulau Punjung in West Sumatera that an angry mob of dozens stormed his office and beat him up. To add insult to injury, police then arrested him and he was sentenced to two-and-a-half years in prison on June 15, 2012, under the Blasphemy Law for publicly declaring himself an atheist (Mandari 2012; The Jakarta Post 2014)

Incidents of violations to freedom of religion and belief in West Sumatera, such as the Aan case and the dissolution of the Ahmadiyah group in Padang, highlight that Minangkabau peoples' attitudes have been influenced by the Salafi-Wahabi movements. Large numbers of Minangkabau people, especially those who live in the urban areas, consider Islam as a religion that has developed a new paradigm, replacing their existing culture. Thus Islam is viewed as a religion that appears to change the whole system of culture, especially the pre-Islamic Arabia. The pre-Islamic period is often considered as a period of un civilised attitudes (jabiliyah). These Islamic groups certainly consider the matrilineal and land tenure systems in Minangkabau as pre-Islamic culture and part of jahiliyah culture that needs to be eliminated. Ustadz Amir Bahar, a member of HTI from Malalo village, Tanah Datar, stated that:

"Ultimately, the matrilineal and land tenure systems in Minangkabau oppose sharia law. Islam is a perfect religion, which not only lays the fundamentals for worship but also of politics and the state (din wa daulah). There- 
fore, we have to eliminate the matrilineal system in Minangkabau. God, through the Prophet Muhammad had made the sharia for Muslims. Sharia is the rules set by God that must be implemented in the life of society and humanity." 28

A similar argument was also expressed the government officials and business communities. There has been numerous development and investment projects that have had to be postponed due to land acquisition problems. In an interview with Risorafrom Tanah Datar, a businessman of bauxite mining companies operating in Tanjungpinang, stated:

"Many investments and infrastructure projects could not be realized due to land acquisition problems in West Sumatera. Based on my experience for more than 10 years doing business in my hometown in West Sumatera, getting the land is the last and highest hurdle. The local governments have to be able to change the land ownership system if they want to develop their region."

As a result, conflicts arise, both among indigenous communities (internal conflict-horizontal), and between indigenous peoples with a third party (external conflict-vertical), especially with the government and private companies. From 2004 to 2008 there were 116 cases of conflict over 125.924 hectares of Tanah Pusako in West Sumatera (LBH-Padang 2010).

\section{Conclusion}

The evidence shows that the interpretations of sharia in Minangkabau are very dynamic. Both those who support and oppose the Minangkabau customary laws, use sharia to legitimise their points of view. The character of sharia in the history of Islam, including in Minangkabau land, has changed over the

\footnotetext{
28 The interview was conducted on 26 November 2015.
} 
centuries and the understanding of sharia is now fundamentally different from what it was at the time sharia law developed in the seventh and eighth centuries. Many proponents of the formal implementation of sharia in Indonesia, in this case in Minangkabau, emphasize only the legal subject matter in defining the sharia. In many cases, they use the words hukm or ahkam (legal) to characterize sharia as a legal subject matter. No wonder then, that the term sharia is used interchangeably with 'Islamic law'. Misinterpretation of the development in the adat of inheritance and sharia discourse in Minangkabau has resulted in a superficial conclusion. Unfortunately, these biases become manifest, on one hand, in a dramatization of the matrilineal principle as more or less the only one which structured "past" Minangkabau society; on the other hand in an equally strong dramatization of any change or deviance from this hypothesized matrilineal.

\section{Bibliography}

A'la, Abdul. 2008. "The Genealogy of Muslim Radicalism in Indonesia: A Study of the Roots and Characters of the Padri Movement." Journal of Indonesian Islam 2 (2).

Abdullah, Taufik. 1966. "Adat and Islam: An Examination of Conflict in Minangkabau.” Indonesia 2 (October): 1-24.

Abunain, Syafnir. 1991. Sumpah Satie Di Bukit Marapalam, Perpaduan Antara Adat Dengan Syarak. Padang: Universitas Andalas.

Al-Syatibi, Abu Ishaq. 1302. Al-Muwafaqaat Fi Usul Al-Shari'ah. Tunisia: Dawlat Al-Tunisia.

Al-Zuhaili, Wahbah. 1986. Ushul a-Fiqh Al-Islami. Beirut: (Dar al-Fikr al-Mu'ashir.

Alcoff, Linda Martin. 2013. "Epistemology and Politics.” Radi- 
cal Philosophy Review 16 (3).

Anderson, J.N.D. 1967. "The Eclipse of The Patriarchal Family in Contemporary Islamic Law." In Family Law in Asia and Africa, edited by J.N.D Anderson. New York: Frederick A. Praeger.

Ash-Shiddiqy, Hasbi. 1966. Syariat Islam Menjawab Tantangan Zaman. Jakarta: Bulan Bintang.

Asnan, Gusti. 2003. "Penguasa Militer Dan Pemerintahan Daerah: Sumatera Barat Akhir 1950-an Dan Awal 1960-An.” Analisis CSIS, no. 4.

Asoka, Andi. 1991. "Sumpah Satie Bukit Marapalam, Antara Mitos Dan Realitas." In Sejarah Perpaduan Antara Adat Dan Syarak Di Sumatera Barat. Padang: Faculty of Humanity Andalas University and the Local Government of West Sumatera.

Azizy, A. Qadri. 2002. Eklektisisme Hukum Nasional Kompetisi Antara Hukum Islam Dan Hukum Umum. Yogyakarta: Gama Media.

- 2003. Reformasi Bermazhab: Sebuah Ikhtiar Menuju Ijtihad Sesuai Saintifik Modern. Jakarta: Teraju.

Azra, Azyumardi. 2003. "Bali and Southeast Asian Islam: Debunking the Myths." In After Bali: The Threat of Terrorism Southeast Asia, edited by Kumar Ramakhishna and See Seen Tan. Singapore: Institute of Defence and Strategic Studies Nanyang Technological University and World Scientific Publishing.

Berger, Peter L. 1967. The Sacred Canopy: Elements of a Sociological Theory of Religion. Garden City, NY: Doubleday.

Blackwood, Evelyn. 2001. "Representing Women: The Politics 
SHARIA, TWO SIDES OF THE SAME COIN

of Minangkabau Adat Writing." The Journal of Asian Studies 60 (1).

Dobbin, Christine. 1977. "Economic Change as a Factor in the Rise of the Padri Movement, 1784-1830.” Indonesia, no. 23.

. 1987. Islamic Revivalism in Changing Peasant Economy Central Sumatera, 1787-1847. London: Curzon Press.

Drakard, Jane. 1999. A Kingdom of Words: Language and Power in Sumatera (South-East Asian Historical Monographs). New York: Oxford University Press.

Esposito, John L. 1982. Women in Muslim Family Law,. Syracuse NY: Syracuse University Press.

Evers, Hans-Dieter. 1975. "Changing Patterns of Minangkabau Urban Landownership.” Bi Jdragentot de Taal-, Land-En Volkenkunde, no. 131.

Fanany, Ismet. 2003. "The First Year of Local Autonomy the Case of West Sumatera." In Autonomy and Disintegration in Indonesia. New York: Psychology Press.

Franz, Benda-Beckmannn, and Benda-Beckmannn Keebet von. 2006. "Changing One Is Changing All: Dynamics in the Adat-Islam-State Triangle." The Journal of Legal Pluralism and Unofficial Law 38 (53-54): 239-70. doi:10.1080/073 29113.2006.10756604.

Fuller, Graham E. 2003. The Future of Political Islam. New York: Palgrave Macmillan.

Geertz, Clifford. 1968. The Religion of Java. New York: The Free Press.

Graves, Elizabeth E. 1984. The Minangkabau Response to Dutch 
Colonial Role in the Nineteenth Century. New York: Cornell Modern Indonesia Project.

Hallaq, Wael B. 2009. An Introduction to Islamic Law. Cambridge University Press.

Hamka. 1984. Islam Dan Adat Minangkabau. Jakarta: Pustaka Panjimas.

Hasani, Ismail (ed.). 2009. "Laporan Kondisi Kebebasan Beragama/berkeyakinan Di Indonesia 2008: Berpihak Dan Bertindak Intoleran (Intoleransi Masyarakat Dan Restriksi Negara Dalam Kebebasan Beragama/Berkeyakinan Di Indonesia).” Jakarta: Setara Institute.

Hazairin. 1982. Hukum Kewarisan Bilateral Menurut Qur'an Dan Hadits. Jakarta: Tintamas.

Hjarpe, J. 1983. "The Attitudes of Islamic Fundamentalism Towards the Question of Women in Islam." In Women in Islamic Societies: Social Attitudes and Historical Perspective, edited by B. (ed.) Utas. London: Curzon Press.

Hobbes, Thomas. 1651. Leviathan, or The Matter, Forme, \& Power of a Common-Wealth Ecclesiasticall and Civill. London: The Green Dragon in St. Pauls Church-yard.

Hurgronje, C. Snouck. 2007. Mecca in the Later Part of 19th Century. Edited by J.H. Monahan. Vol. 1. Leiden; Boston: Brill.

Jeffrey, Hadler. 2008. Muslims and Matriarchs: Cultural Resilience in Indonesia Through Jihad and Colonialism. Ithaca; London: Cornell University Press.

Jong, PE de Josselin de. 1960. Minangkabau and Negeri Sembilan: Socio-Political Structure in Indonesia. Jakarta: Bhrata. 
Kahn, Joel S. 2007. Minangkabau Social Formation, Indonesian Peasants and World Economy. Cambrdige: Cambridge University Press.

Karim, Khalil Abdul. 2003. Al-Judzur Al-Tarikhiyyah Li AlSyariah Al-Islamiyyah, (Syari'ah Sejarah Perkelahian Pemaknaan). Translated into Bahasa Indonesia. Yogyakarta: LKiS.

Kato, Tsuyoshi. 2005. Adat Minangkabau Dan Merantau Dalam Perspektif Sejarah. Jakarta: Balai Pustaka.

Khadduri, Majid. 2010. War and Peace in the Law of Islam. New Jersey: The Lawbook Exchange Ltd.

Koentjaraningrat. 1974. Kebudayaan, Mentalitet Dan Pembangunan. Jakarta: Gramedia.

Kottak, Conrad Phillip. 2006. Mirror for Humanity : A Concise Introduction to Cultural Anthropology. New York: McGraw Hill.

LBH-Padang. 2010. "Database of Padang Legal Aid Agency.” Padang.

Locke, John. 1690. "Essay Concerning Human Understanding.” Loeb, Edwin. 1934. "Patrilineal and Matrilineal Organization in Sumatera." American Anthropological Association, New Series 36 (1).

Lukito, Ratno. 2001. Islamic Law and Adat Encounter: The Experience of Indonesia. Jakarta: Logos.

Mandari, Presi. 2012. "Calls to Behead Indonesian Atheist Alexander Aan.” Jakarta Globe. http://jakartaglobe.id/archive/ calls-to-behead-indonesian-atheist-alexander-aan/.

Maretin, J. V. 1961. “Disappearance of Matriclan Survivals in 
Minangkabau Family and Marriage." Bijdragen Tot de Taal-, Land-En Volkenkunde, no. 117.

Moubray, G. A. de. 1931. Matriarchy in the Malay Peninsula and Neighbouring Countries. London: Routledge and Sons.

Navis, A.A. 1991. Bukit Marapalam. Padang: Universitas Andalas.

Philips, Abu Ameenah Bilal. 2000. The Evolution of Figh: Islamic Law \& the Madhhabs. Riyadh: International Islamic Publishing House.

Prins, Jan. 1951. "Adat Law and Muslim Religious Law in Modern Indonesia: An Introduction.” Die Welt Des Islams, New Series, 1 (4).

Qardhawi, Yusuf. 1996. Keluwesandan Keluasan Syari'ah Islam Dalam Menghadapi Perubahan Zaman (Indonesia Traslation). Jakarta: Pustaka Firdaus.

Reenen, Joke Van. 1996. Central Pillars of the House: Sisters, Wives, and Mothers in Rural Community in Minangkabau, West Sumatera. Leiden: Research School, CNWS.

Sanday, Peggy Reeves. 2003. Women at the Center: Life in a Modern Matriarchy. Ithaca: Cornell University Press.

Schact, J. 1964. An Introduction of Islamic Law. Oxford: Clarendon Press.

Shabana, Ayman. 2010. Custom in Islamic Law and Legal Theory: The Development of the Concepts of 'Urf and 'Adah in the Islamic Legal Tradition. New York: Palgrave Macmillan.

Simarmata, Rikardo. 2006. Pengakuan Hukum Terhadap Masyarakat Adat Di Indonesia. Jakarta: RIPP-UNDP. 
Sirry, Mun'im A. 1996. Sejarah Fiqih Islam: Sebuah Pengantar. Surabaya: Risalah Gusti.

Storey, John. 1997. An Introduction to Cultural Theory and Popular Culture. New Jersey: Prentice Hall International Inc.

Syarifuddin, Amir. 1984. Pelaksanaan Hukum Kewarisan Islam Dalam Lingkungan Adat Minangkabau. Jakarta: Gunung Agung.

Tahrir, Hizbut. 2005. Ajhizah Ad-Dawlah Al-Khalifah. Beirut, Lebanon: Dar al-Ummah.

The Jakarta Post. 2014. "Atheist Alexander Aan Gets of Prison." The Jakarta Post. http://www.thejakartapost.com/ news/2014/01/31/atheist-alexander-aan-gets-prison.html.

Tylor, Edward B. 1871. Primitive Culture: Researches into the Development of Mythology, Philosophy, Religion, Art, and Custom. London: J. Murray.

Wahid, Abdurrahman. 1989. "Pribumisasi Islam.” In Islam Menatap Masa Depan, edited by Muntaha Azhari and Abdul Mun'im Saleh. Jakarta: P3M.

Woodward, Mark R. 1989. Islam in Java: Normative Piety and Mysticism in the Sultanate of Yogyakarta. Arizona: University of Arizona Press.

Zakariya, Hafiz. 2011. "From Makkah to Bukit Kamang?: The Moderate versus Radical Reforms in West Sumatera (Ca. 1784-1819)." International Journal of Humanities and Social Science 1 (October): 195-203. 
This page intentionally left blank 